\title{
In-service EFL Teacher Development for Technology Integration in Communicative Language Teaching
}

\author{
Kwangsawad, Thooptong \\ Faculty of Education, Mahasarakham University (THAILAND) \\ *Corresponding author's email: thooptongk [AT] hotmail.com
}

\begin{abstract}
In response to the challenges of ASEAN Economic Community 2015, Ministry of Education announced the latest policies to reform teaching and learning English at the basic education level adapting communicative language teaching (CLT) flexibly and appropriately to the Thai context, and using information computer technology (ICT) media as a tool to enhance teaching skills and knowledge of teachers. This article deals with the implementation and evaluation a professional development program for technology integration in CLT for 32 in-service EFL teachers from primary and secondary school levels with the foci on 1) evaluation of the in-service EFL teachers' knowledge and skills in CLT and technology integration in CLT and, 2) the in-service EFL teachers' experiences with participating in the program. The results show that the post- test scores of the in-service teachers' knowledge in CLT and technology integration in CLT were significantly higher than the pre-test scores. However, their skills in CLT and technology integration in CLT were at the low level. Almost all participants reported having positive experiences with the program.
\end{abstract}

Keywords - in-service EFL teacher development program, CLT, technology integration in communicative language teaching

\section{INTRODUCTION}

Thailand is facing dramatic changes, domestically and in the international arena, that are having an impact on the national development. Particularly ASEAN Community challenges Thai people's English skills. AEC 2015, as known as ASEAN Economic Community 2015, brings a new era of economic cooperation to all 10 countries. And the all 10 countries agree to use English as the language for business. The English skill level of Thai people when compared to other ASEAN countries, except Brunei, Thailand is only ahead of Laos, Cambodia, Burma, and Vietnam. Thailand lags far behind major ASEAN countries like Malaysia, Philippines, Indonesia, and Singapore ("English upgrade needed", 2014). Thai people need to improve their capacity to communicate in English to compete in the AEC labor market. As a result, one of important education goal is developing fluency in the English language among Thai students to make better prepared for economic competitiveness as a nation as the change of globalization and the establishing of ASEAN community. There is an urgent need to find effective teaching strategies for students who will soon learn in universities, preparing them for AEC and for working in the global marketplace.

Recognizing the importance and need to further develop the English language teaching profession and learning environment in the ASEAN region, in the year 2015, the Ministry of Education announced the latest policies to reform teaching and learning English at the basic education level using Common European Framework of Reference for Languages (CEFR) for English learning, teaching and assessment, adapting CLT flexibly and appropriately in the Thai context, and learning English in order to use ICT media for education as a tool to develop the abilities of teachers to enhance teaching skills. Moreover, the Ministry of Education is improving quality of English language education. Systematic improvement in pedagogical skills, language proficiency, classroom research, and also testing and evaluation skills of in-service teachers, along with the development of pre-service teachers is undertaken in cooperation with higher education institutions as well as with agencies of native English speaking countries (Ministry of Education, 2015).

Traditionally, a typical English classroom in Thailand is either teachers' use of grammar-translation or audio-lingual methods (Saengboon, 2006). Prapaisit de Segovia \& Hardison (2008) conducted a study on the implementation of CLT in the Thai context and revealed that despite the new curriculum reform stipulated by the Education Educational Act, most Thai EFL teachers still used the traditional teaching methods they were familiar with, and little or no evidence of communicative language use found from several observations of English classes.

Regarding professional development for technology integration in Thailand, Waitayangkoon (2004) conducted a case study and found that the Ministry of Education and the ICT Unit in the Office of the Permanent Secretary of Education provided in-service teacher training courses at three levels: foundation, intermediate, and advance. The foundation level was a requirement for all teachers, including necessary general purpose software such as databases, word processing, spreadsheets, and the internet use. The intermediate level courses were optional for teachers. The courses focused on developing teaching materials that required higher levels of ICT skills such as ready-made templates, web authoring 
tools, developing web materials using presentation programs, and developing simple CAI programs using authoring software. The advanced level courses were designed for teachers who taught computer courses. None of these courses was connected to content teaching. Many teachers were not able to integrate ICT skills that they had learned into their classrooms. Also, the researcher conducted context analysis and found that the in-service EFL teachers taught English without any technology support to enhance students' learning. For example, in listening classes, many in-service EFL teachers did not use authentic listening materials such as TV and radio news, cartoons, songs, etc. which is crucial to expose official spoken language by native speakers of English to students. From this evidence, the researcher argues that there are some contributing factors, one of which is the in-service EFL teachers' lack of knowledge and skills in integrating technology into their classrooms, which is one of the main barriers to technology integration. In response to this problem, the present study proposes to implement a project on "The COUPON for teacher development program" which is a nationwide annual program that aims to empower teachers and improve the country's teaching profession regarding knowledge and skills through real practices. The program involves collaboration between the Office of the Basic Education Commission and 46 universities. The program helps teachers develop skills as per job requirements through the use of "coupons" and upgrade their teaching to be on par with international standards. Each teacher is given a set of coupons, which they can then exchange for the right to take training courses. The universities provide close support and guidance to achieve useful results. Initially, teachers develop individual plans. After that, the plans delivered to the Educational Service Area Offices, which decide on the procedures for each group of teachers before dealing with the universities that are part of the collaboration.

Faculty of Education, Maharakham University is one of the 46 participating universities which in charge of the COUPON for teacher development program. The researcher and two instructors were responsible for organizing this program. Thirty-two in-service EFL teachers who were interested in CLT and using technology in the classrooms were selected by the Educational Service Area Offices to participate in the program at Mahasarahkam University. To meet the teachers' interest, the researcher and two instructors offered the technology integration in CLT program in order to adapt CLT and develop technology integration skills that align with CLT for them.

As was previously stated, the latest policies to reform teaching and learning English in the basic education level focus on adapting CLT flexibly and appropriately to the Thai context, and using ICT media for education as a tool to develop the abilities of teachers and to enhance the teaching skills and knowledge of teachers. By context analysis, the in-service teachers lack knowledge and skills in integrating technology into their English classrooms. ICT thus indicates a need for an efficient, professional development program to cope with such a problem. Therefore, the study aimed at implementing and evaluating the COUPON for teacher development program for technology integration in CLT for the in-service EFL teachers. To evaluate the program, two questions of this study addresses:

1. Do the in-service EFL teachers' knowledge and skills improve as the results of participation in the COUPON for teacher development program? The effectiveness of the program evaluated through improvement of their knowledge in CLT and technology integration in CLT, and skills in CLT and technology integration in CLT.

2. What are the in-service EFL teachers' experiences with participating in the COUPON for teacher development program? The practicality of the program evaluated during reflection phase. Reflection allowed the pre-service EFL teachers to share their teaching and the researcher to find out their needs, suggestions, difficulties, and improvement that they experienced during attending the program.

\section{LITERATURE REVIEW}

\subsection{Teacher Profession Development on Technology Integration}

Instructional technology integration will occur across all grade levels and in all content areas when it is supported by professional development. The goal of successful technology professional development is its integration into teaching to impact student learning. Some researchers emphasize the need for career development programs which teachers engage in inquiry and reflect on their practices to improve their learning about technology integration (Loucks-Horsley et al., 2003; Zeichner, 2003). Mishra and Koehler (2006) describe three types of knowledge that teachers need to adopt ICT in their classrooms effectively: technology, pedagogy, and content. Teachers might not be able to use technology appropriately without an effective on-going teacher professional development on these three types of knowledge. Training of teachers is a key aspect of almost every education improvement strategy and creates the largest component of educational reform programs (Majumdar, 2005; Valanides \& Angeli, 2006; MacDonald, 2009). ICT knowledge and skill-based courses are not enough for preparing teachers to integrate ICT in classrooms since they are taught in separation from a pedagogical context. Professional development models that do not focus on subject-specific pedagogy will lead to teachers having difficulties in linking technology with pedagogy. From this reason why many teachers who have received ICT training as part of their professional development still lack the confidence because the limitation in ICT integration skills makes them feel anxious about using ICT in the classroom and thus not confident to use it in their teaching (Harris, Mishra, \& Koehler, 2009).

\subsection{Communicative Language Teaching}

Communicative language teaching (CLT) is a pedagogical approach to achieve communicative purposes since the current trend in ESL and EFL teaching focuses on students' ability to communicate effectively in meaningful ways. Nunan (1999) emphasizes that in the current language education, teachers do not teach about language; rather, they teach 
language. They expect students to use English naturally in a meaningful way; this language competency is thus measured from how well students can use it for various purposes in real contexts. The goal of teaching English focuses on fluency and accuracy. Richards (2006) also describes that CLT is a broad approach to teaching which emphasizes the process of communication rather than just focusing on grammar. Richards divides CLT practice into three different kinds of practice - mechanical, meaningful and communicative.

Mechanical practice refers to a controlled practice activity which students can successfully carry out without necessarily understanding the language they are using. Examples of this kind of activity would be repetition drills and substitution drills designed to practice use of particular grammatical or other items.

Meaningful practice refers to an activity where language control is provided but where students are required to make meaningful choices when carrying out practice. For examples, to practice the use of prepositions to describe locations of places, students might be given a street map with various buildings identified in different locations. They are also given a list of prepositions such as near, on, across from, on the corner of, next to. They then have to answer questions such as Where is the book shop? Where is the café?, etc. The practice is now meaningful because they have to respond according to the location of places on the map.

Communicative practice refers to an activity where practice in using language within a real communicative context is the focus, where real information is exchanged, and where the language is not totally predictable. For example, students might have to draw a map of their neighborhood, such as the nearest bus stop, the nearest café, etc.

\subsection{The COUPON for Teacher Development Program}

\section{METHODOLOGY}

The program was designed in six-month program and conducted in 2015 . With regard to active engagement, the inservice EFL teachers became the chief designers who actively participated in developing their lesson plans. The program started with a workshop, followed by lesson plan development. It then required the in-service EFL teachers to implement the developed lesson plans. Practical and technical supports were given during the program by three facilitators (the researcher and two instructors) to enhance learning. Four phases were undertaken to provide the in-service EFL teachers with authentic learning experiences during the program. Each phase is shortly detailed below.

\subsubsection{Workshop}

The first phase was a two-day workshop on CLT and technology integration in CLT, involving 32 in-service EFL teachers who participated in this program. The workshop was provided them with knowledge and skills in CLT and how to integrate technology into CLT lesson plans. Three facilitators for the workshop were involved. The first facilitator was the researcher who introduced CLT, curriculum content and CLT lesson plans, while the second and the third facilitators presented technology integration in CLT. The contents of this workshop are listed in the table below.

Table 1: Workshop contents

\begin{tabular}{ll}
\hline Day & Topics \\
\hline Day 1 & Pre-test \\
& CLT \\
& CLT lesson plan \\
& Technology integration in CLT \\
Day 2 & Demonstration of technology integration in CLT \\
& Integrating technology into CLT lesson plans \\
\hline
\end{tabular}

\subsubsection{Lesson Plan Development}

The second phase was lesson plan development phase. For this phase, each in-service EFL teacher developed a lesson plan based on aligning technology with CLT that fit with the curriculum, while the three facilitators were only to facilitate and gave supports during the process. This phase was aimed at providing them with the opportunity and experiences to integrating technology into CLT lesson plans.

\subsubsection{Implementation of the Lesson Plans}

The third phase was implementation of the lesson plan phase. For this phase, each in-service EFL teacher performed the developed lesson plan with students in the real classroom. The three facilitators observed their classrooms.

\subsubsection{Reflection}

The fourth phase was reflection phase. The reflective teaching was conducted in a meeting attended by all inservice EFL teachers, the researcher and two instructors at the end of the program. The in-service EFL teachers were requested to sit in group of five to reflect on the lesson plans that they implemented. At this point, they had an opportunity to exchange ideas within a caring and sharing atmosphere. They were also required to write comments and suggestions which focused on contents, technologies, and pedagogies that helped students to reach the goals, how both 
students and the teachers achieved or failed to participate in the activities, what problems they faced and how they solved the problems.

\subsection{Participants}

This study involved 32 in-service EFL teachers from secondary and primary schools from three Educational Service Area Offices selected by the Educational Service Area Offices to participate the program at Mahasarahkam University. Their teaching experience ranged from 3-28 years. They were between 27-58 years of age. Before attending the program, they were not familiar with CLT. They taught English without any technology support to enhance students' learning. Almost all of them possessed smartphones, using social media and spending 1-7 hours on the Facebook and online chatting.

\subsection{Data Collection}

This study used quantitative and qualitative techniques to collect data. The participants were asked to complete and turn in the pre-test before the workshop began, by evaluating the knowledge in CLT and technology integration in CLT. The post-test was collected at the workshop conclusion. To evaluate skills in CLT and technology integration in CLT, the researcher assessed the lesson plans during the lesson plan development phase and assessed the ability to perform the developed lesson plans with students in the real classrooms during the implementation of the lesson plan phase. In the implementation of the lesson plan phase, the participants were observed by the researcher and two instructors 40-minute period of instruction for each teacher. The researcher used the criteria based on the adapted Technology Integration Assessment Rubric from Harris, Grandgenett and Hofer (2010) to assess the lesson plans and the implementation of the lesson plans. There are six categories rated using a 4 point-scale, each point having specific explanations. The categories are as follows: (1) curriculum goals and technologies; (2) instructional strategies and technologies; (3) technology selection(s); (4) fit; (5) instructional use; and (6) technology logistics. Each category receives a score from 1 to 4, with specific explanations. The first four categories were used to assess the lesson plans while the last two categories were used to assess the implementation of the lesson plans. To investigate the in-service EFL teachers' experiences with participating in the program, the researcher observed and took note. The participants were also required to write the reflection during the reflection phase.

\subsection{Data Analysis}

The data collected for this study was analyzed quantitatively and qualitatively. Data from pre-test and post-test were compared to identify the difference by using t-test dependent and data from assessment of the lesson plans and implementation of the lesson plans were analyzed using mean and standard deviation. On the other hand, data from reflection were coded into some categories and translated into English. This coding aimed at breaking the data into categories. The researcher then generated the categories based on emerging themes.

\section{FINDINGS \\ 4.1 Knowledge and Skills in CLT and Technology Integration in CLT}

This evaluation addresses the effectiveness of the program. The question being addressed for this goal is that: Do the in-service EFL teachers' knowledge and skills improve as the results of participation in the COUPON for teacher development program? Two instruments were used to collect the data needed for the purpose of answering such a question: pre-test and post-test, and the adapted Technology Integration Assessment Rubric to assess the lesson plans and implementation of the lesson plans. All these are discussed respectively in the following sub-sections.

\subsubsection{Knowledge in CLT and Technology Integration in CLT}

Based on t-test dependent, the post-test scores of CLT and technology integration in CLT knowledge were significantly higher than the pre-test scores. Therefore, it can be concluded the results from pre-test and post-test that the in-service EFL teachers' knowledge in CLT and technology integration in CLT increased after attending the COUPON for teacher development program. The data is presented in table 2 and 3. 
Table 2: Pre-test and post-test scores of the in-service EFL teachers' knowledge in CLT and technology integration in CLT

\begin{tabular}{|c|c|c|}
\hline $\begin{array}{c}\text { Participants } \\
32 \\
\end{array}$ & $\begin{array}{c}\text { Pre-test } \\
20 \\
\end{array}$ & $\begin{array}{c}\text { Post-test } \\
20 \\
\end{array}$ \\
\hline 1 & 6 & 10 \\
\hline 2 & 3 & 7 \\
\hline 3 & 13 & 13 \\
\hline 4 & 11 & 14 \\
\hline 5 & 10 & 16 \\
\hline 6 & 4 & 7 \\
\hline 7 & 8 & 11 \\
\hline 8 & 10 & 13 \\
\hline 9 & 12 & 14 \\
\hline 10 & 7 & 11 \\
\hline 11 & 5 & 5 \\
\hline 12 & 4 & 3 \\
\hline 13 & 6 & 11 \\
\hline 14 & 10 & 10 \\
\hline 15 & 9 & 12 \\
\hline 16 & 8 & 12 \\
\hline 17 & 2 & 7 \\
\hline 18 & 7 & 9 \\
\hline 19 & 11 & 12 \\
\hline 20 & 12 & 13 \\
\hline 21 & 3 & 7 \\
\hline 22 & 5 & 6 \\
\hline 23 & 7 & 9 \\
\hline 24 & 4 & 8 \\
\hline 25 & 9 & 11 \\
\hline 26 & 7 & 11 \\
\hline 27 & 8 & 12 \\
\hline 28 & 11 & 11 \\
\hline 29 & 3 & 7 \\
\hline 30 & 6 & 9 \\
\hline 31 & 9 & 13 \\
\hline 32 & 4 & 12 \\
\hline
\end{tabular}

Table 3: Comparison of pre-test and post-test scores of the in-service EFL teachers' knowledge in CLT and technology integration in CLT

\begin{tabular}{lcccccc}
\hline & $\mathrm{N}$ & $\overline{\mathrm{X}}$ & $\mathrm{S} . \mathrm{D}$. & $\mathrm{t}$ & $\mathrm{df}$ & $\mathrm{p}$ \\
\hline Post-test & 32 & 10.1250 & 3.07369 & & & \\
Pre-test & 32 & 7.3125 & 3.04536 & -8.265 & 31 & .000 \\
& & & & & & \\
\hline
\end{tabular}

The total means show that the in-service EFL teachers improved their total scores in the post-test. The difference between pre-test and post- test was significant at the 0.05 level. It can be concluded that the COUPON for teacher development program served the purpose.

\subsubsection{Skills in CLT and Technology Integration in CLT}

To assess the lesson plans, data were analyzed using the criteria based on the adapted Technology Integration Assessment Rubric (the first four categories) from Harris, Grandgenett and Hofer (2010). The description of the data is presented in the table below. 
Table 4: Mean scores of the in-service EFL teachers' lesson plan assessment

\begin{tabular}{lcc}
\hline Criteria & Mean & S.D. \\
\hline $\begin{array}{l}\text { Curriculum Goals \& Technologies } \\
\text { (Curriculum-based technology use) }\end{array}$ & 2.25 & 0.80 \\
$\begin{array}{l}\text { CLT \& Technologies } \\
\text { (Using technology in CLT) }\end{array}$ & 2.09 & 0.81 \\
$\begin{array}{l}\text { Technology Selection (s) } \\
\text { (Compatibility with curriculum goals \& CLT) }\end{array}$ & 1.91 & 0.76 \\
$\begin{array}{l}\text { "Fit" } \\
\text { (Content, CLT and technology together) }\end{array}$ & 1.63 & 0.75 \\
\hline
\end{tabular}

The total means show that the in-service EFL teachers' skills in developing technology integrated in CLT lesson plans were at the low level.

To assess the implementation of lesson plans, data were analyzed using the criteria based on the adapted Technology Integration Assessment Rubric (the last two categories) from Harris, Grandgenett \& Hofer (2010). The description of the data is presented in the table below.

Table 5: Mean scores of the in-service EFL teachers' implementation of lesson plans

\begin{tabular}{lcc}
\hline \multicolumn{1}{c}{ Criteria } & Mean & S.D. \\
\hline $\begin{array}{l}\text { Instructional Use } \\
\text { (Using technologies effectively for instruction) } \\
\begin{array}{l}\text { Technology Logistics } \\
\text { (Operating technologies effectively) }\end{array}\end{array}$ & 2.16 & 0.77 \\
\hline
\end{tabular}

The total means show that the in-service EFL teachers' skills in implement technology integrated in CLT lesson plans were at the low level.

\subsection{Experiences with Participating in the Program}

As the goal of this research is to implement and evaluate the professional development program for technology integration in CLT classrooms, the goal of the evaluation is, therefore to find out its practicality regarding the in-service EFL teachers' needs, difficulties, and improvement that they experienced during the program. The question thus addresses: What are the in-service EFL teachers' experiences with participating in the COUPON for teacher development program? In collecting the data, the researcher observed the in-service EFL teachers' discussion during the reflection phase. Also, the in-service EFL teachers had a chance to write the reflection in Thai then, the researcher translated into English after analyzing. The following two main themes emerged from analyzing the data.

\subsubsection{CLT}

Nine in-service EFL teachers believed that they were confident enough with teaching English after following the program. As two teachers wrote:

"...At first, I had a lot of reservations about participating in this program because I am busy. Now, I realize that the program has helped me see past some blind spots in my teaching. Before attending this program, it was difficult to open up my classroom to a colleague, now I am gaining a sense of confidence, which outweighs the anxiety. Most of all, I have increased awareness of the importance of actively "thinking” about my teaching ...."

“... I will continue using CLT even though you won't observe me any longer. I plan to prepare materials during summer. I will look for new activities and apply them carefully for my students. Well, as you know lesson plans are required in schools so I will do them by myself. In the past, I did not know how to do them and why I had to do them but I know how to do them now. CLT can help me! I can have my own lesson plans as long as I use CLT..."

Seven teachers appeared to understand the concept of CLT. Prior to this workshop, they thought that CLT concentrated on fluency and neglected accuracy. This can be seen in one teacher's comment.

“...Before attending this program, I thought that CLT did not teach grammar and only taught speaking. I did not think that was a good way to teach our students reading ..."

During the discussion the researcher found that CLT teaching skills that all of the teachers needed to develop were (1) distinguishing between " meaningful" and "communicative" activities; (2) designing "meaningful" and "communicative" activities and preparing materials based on units and topics from the Basic Core Curriculum A.D.2008; (3) giving appropriate time for each activity based on students' abilities; (4) using L2 (Most in-service EFL teachers did 
not use English as the medium of instruction for most of their teaching time); and (5) minimizing teacher talk time (TTT). Five teachers said: students..."

“...I made a mistake during the class. I think I spoke too much. I should provide more activities for my

“...I tried to use English in my classrooms, but I could do so for only for 5-10 minutes...”

“...I was struggling with selecting meaningful and communicative activities. I spent a lot of time trying to design those activities..."

“...I am confused between meaningful activities and communicative activities...”

“...Preparing activities and materials involved for me. I need to think about, "mechanical, meaningful and communicative” activities and lots of work..."

\subsubsection{Technology integration in CLT}

Ten teachers reported that it was a necessity for teachers to keep up with current technologies. They believed that the program could improve their teaching skills. One teacher said:

“...Technology has been developing rapidly, and in this respect, we are supposed to participate in activities and training that will help develop our knowledge... for example, during the training that you taught me how to download text to speech software programs. You know, these programs contribute to improving my students' listening skills..."

Almost all of the in-service EFL teachers mentioned that they could use graphics coupled with animation functions in PowerPoint for reviewing vocabulary because this kind of technology did not require higher level computer skills. One teacher said:

“...I can use graphics and pictures to teach vocabulary during the presentation step, but I just don't have any idea to use technology in mechanical practice, and meaningful practice activities..."

However, they believed that their students were more engaged and that they learned more when they used technologies in their classrooms. One teacher wrote:

“...I used pictures to help my students got the meaning of vocabulary. The students could hear me talking, and then they saw the picture of it immediately, they made a little bit better connection with it..."

Six teachers expressed appreciation for the ease of using videos and internet access. One of them wrote:

“... Now, I can download videos from internet sites, or I can find them on YouTube. Before attending the program, I didn't know how to download videos and search information from the web..."

Four teachers shared about the program they mentioned that the program allowed them to try out new technology in their classrooms. They had a chance to explore new technologies, and to find new ways to implement them. One teacher wrote:

"...I had a chance to work on what I had learned from the workshop. When you go to the training, you get to try everything and you get to work it out. If you are working on a certain program you have to work on that program instead of just listening to somebody or watching a presentation. You really get to be part of it..."

Another teacher expressed about workshop.

"I had positive experiences with support during the workshop. I was not afraid to ask questions. The instructors were very supportive, always available to answer questions never condescending..."

\section{DISCUSSION}

The results of this study suggest that the COUPON for teacher development program was successful, viewed from the participants' positive experiences. This study confirms the findings of the previous studies (e.g., Chamorro Rey, 2013; Liu \& Kleinsasser, 2015; Ansyari, 2015). It can be argued that the in-service EFL teachers gain knowledge in CLT and technology integration in CLT. Regarding the lack of competencies level of the in-service EFL teachers regarding technology integration skills, Almekhlafi and Almeqdadi (2010) suggest that providing workshops that allow teachers to reflect upon effective strategies for technology integration into instruction and unveil issues that are central to understanding the process of technology integration into instruction can increase the awareness of teachers about the pratical use of technology in the classroom. Moreover, reflection impels teachers to shape their beliefs. Loucks-Horsley et al. (1998) point out that the reflection phase is a vital part of the professional development program because it is based on the actual results of the implemented professional development program on student learning and teacher's beliefs. 
The primary challenge in this program was the implementation of the lesson plan phase that each teacher performed the developed CLT lessons with students in the real classrooms. And the researcher and two instructors observed their classrooms. The researcher found that classroom observations were a waste of time and budget. This finding suggests the program developers might use other tools (e.g., video or Skype) in case they are not available for visiting the classroom.

The results of this study imply that the COUPON for teacher development program increases awareness about technology use integrated with language pedagogy. Rather than viewing professional development as a way to allow teachers to expand on a particular knowledge base, perhaps we should view professional development programs as an opportunity to bring the areas of technology and language pedagogy together, as one knowledge base that aims at enhancing the intersection of knowledge domains that guide effective teaching. In addition, the COUPON for teacher development program can help the in-service EFL teachers see the relevance of their professional learning activities for teaching in their schools, and respect professional development with a coherent connection between their experiences and their actual classroom practice. The COUPON for teacher development is the driving force for teachers to keep improving themselves in action.

\section{CONCLUSION}

Thai people need to improve their capacity to communicate in English to compete in the AEC labor market. Workers with better English skills will also help improve the Thai economy and make the country more competitive; it will also attract more foreign investment to benefit Thailand. One of important education goal is improving fluency in English language among Thai students in order to make better prepared for economic competitiveness. As a result, there is an urgent need to conduct an effective English teaching for students who will soon learn in a university, preparing them for AEC and for working in the global marketplace. Therefore, the study was aimed at implementing and evaluating the COUPON for teacher development program for technology integration in CLT. The results show that the post- test scores of the in-service EFL teachers' knowledge in CLT and technology integration in CLT were significantly higher than the pre-test scores. However, their skills in CLT and technology integration in CLT were at the low level. Almost all participants reported having positive experiences with the program.

\section{REFERENCES}

[1] Almekhlafi, A. G., \& Almeqdadi, F. A. (2010). Teachers' perceptions of technology integration in the United Arab Emirates school classrooms. Educational Technology \& Society, 13 (1), 165-175.

[2] Ansyari, M. F. (2015). Designing and evaluating a professional development programme for basic technology integration in English as a Foreign Language (EFL) classrooms. Australasian Journal of Educational Technology, 31(6), 699-712.

[3] Chamorro, M.G. \& Rey, L. (2013). Teachers' beliefs and the integration of technology in the EFL class. Colombian Journal for Teachers of English, 20,51-72.

[4] English upgrade needed. (2014). Asia Gate Magazine, 2, 72.

[5] Harris, J., Grandgenett, N., \& Hofer, M. (2010). Testing a TPACK-based technology integration assessment instrument. In C. D. Maddux, D. Gibson, \& B. Dodge (Eds.). Research highlights in technology and teacher education. Chesapeake, VA: Society for Information Technology and Teacher Education (SITE).

[6] Harris, J., Mishra, P., \& Koehler, M. (2009). Teachers' technological pedagogical content knowledge and learning activity types: Curriculum-based technology integration reframed. Journal of Research on Technology in Education, 41,393-416.

[7] Liu, M.H. \& Kleinsasser, R.C. (2015). Exploring EFL teachers' CALL knowledge and competencies. Language Learning and Technology, 19,119-138.

[8] Loucks-Horsley, S., Hewson, P., Love, N., \& Stiles, S. (1998). Designing professional development for teachers of science and mathematics. Thousand Oaks, California: Corwin Press.

[9] Loucks-Horseley, S., Love, N., Stiles, K.E., Mundry, S., \& Hewson, P.W. (2003). Designing professional development for teachers of science and mathematics $\left(2^{\text {nd }}\right)$. Thousand Oaks, California: Corwin Press.

[10] MacDonald, R. J. (2009). Professional development for information communication technology integration: Identifying and supporting a community of practice through design-based research. Journal of Research on Technology in Education,40, 429-445.

[11] Majumdar, S. (Ed.). (2005). Regional guidelines on teacher development for pedagogy-technology integration. NESCO Asia and Pacific Regional Bureau for Education.

[12] Ministry of Education, Thailand. (2015). Education for all 2015 review. The World Education Forum (Incheon, Republic of Korea, 19-22 May 2015).

[13] Mishra, P., \& Koehler, M. J. (2006). Technological pedagogical content knowledge: A new framework for teacher knowledge. Teachers College Record, 108, 1017-1054.

[14] Nunan, D. (1999). Second language teaching \& learning. Boston, Massachusetts: Heinle.

[15] Prapaisit de Segovia, L., \& Hardison, D. M. (2008). Implementing education reform: EFL teachers' perspectives.

ELT Journal, 10, 1-9.

[16] Richards, J.C. (2006). Communicative language teaching today. Cambridge: Cambridge University Press. 
[17] Saengboon, S. (2006). CLT revisited. NIDA Language and Communication Journal, 11(11), 136-148.

[18] Valanides, N., \& Angeli, C. (2006). Preparing pre-service elementary teachers to teach science through computer models. Contemporary Issues in Technology and Teacher Education-Science, 6, 87-98.

[19] Waitayangkoon, P. (2004). Integrating ICTs into education: Lessons learned. UNESCO Asia and Pacific Regional Bureau for Education.

[20] Zeichner, K. (2003). Teacher research as professional development for P-12 educators in the USA. Educational Action Research, 11(2), 301-325. 